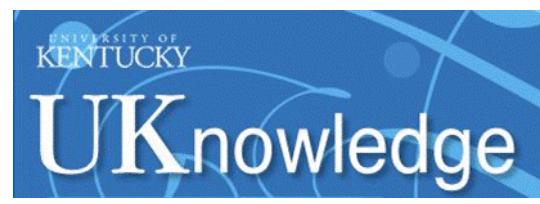

University of Kentucky

UKnowledge

Spring 2018

\title{
The Indigenous Archive: Religion and Education in Eighteenth- Century Mexico
}

Mónica Díaz
University of Kentucky, monica.diaz@uky.edu

Follow this and additional works at: https://uknowledge.uky.edu/hisp_facpub

Part of the Archival Science Commons, Education Commons, History Commons, and the Spanish and Portuguese Language and Literature Commons

Right click to open a feedback form in a new tab to let us know how this document benefits you.

\section{Repository Citation}

Díaz, Mónica, "The Indigenous Archive: Religion and Education in Eighteenth-Century Mexico" (2018).

Hispanic Studies Faculty Publications. 6.

https://uknowledge.uky.edu/hisp_facpub/6

This Article is brought to you for free and open access by the Hispanic Studies at UKnowledge. It has been accepted for inclusion in Hispanic Studies Faculty Publications by an authorized administrator of UKnowledge. For more information, please contact UKnowledge@lsv.uky.edu. 


\section{The Indigenous Archive: Religion and Education in Eighteenth-Century Mexico}

\section{Digital Object Identifier (DOI)}

https://doi.org/10.1353/hir.2018.0013

\section{Notes/Citation Information}

Published in Hispanic Review, v. 86, no. 2, p. 167-183.

Copyright @ 2018 University of Pennsylvania Press. All rights reserved.

All rights reserved. Except for brief quotations used for purposes of scholarly citation, none of this work may be reproduced in any form by any means without written permission from the publisher. For information address the University of Pennsylvania Press, 3905 Spruce Street, Philadelphia, Pennsylvania 19104-4112.

The copyright holder has granted the permission for posting the article here. 


\section{PROJECT MUSE}

The Indigenous Archive: Religion and Education in

Eighteenth-Century Mexico

Mónica Díaz

Hispanic Review, Volume 86, Number 2, Spring 2018, pp. 167-183 (Article)

Published by University of Pennsylvania Press

DOI: https://doi.org/10.1353/hir.2018.0013

$\Rightarrow$ For additional information about this article https://muse.jhu.edu/article/693291 


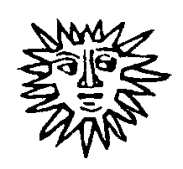

\title{
The Indigenous ARChive: Religion AND EDUCATION IN EIGHTEENTH-CENTURY
}

\author{
MEXICO
}

Mónica Díaz

University of Kentucky

\begin{abstract}
This article argues that eighteenth-century native elites played a significant role in the larger intellectual scene of colonial Mexico by participating in the same debates as their creole and European counterparts. I contend that the documentation produced by native elites related to the indigenous schools (colegios), convents, and seminaries during the eighteenth century provides an important context for understanding the ways in which knowledge circulated between natives, creoles, and Europeans. In addition, when this "indigenous archive" is read in tandem with more traditional historiographical native sources, we can better appreciate the indigenous roots of the dominant narrative of Mexican nationalism. To illustrate the state of fragmentation of what I call an indigenous archive, I discuss the state of the archives of the Jesuit Colegio de San Gregorio and the Franciscan Convent of Corpus Christi.
\end{abstract}

On a warm Thursday morning in the month of May of 2015, I was given the privilege of seeing the entirety of the Franciscan Convent of Corpus Christi's archive in Mexico City, which I hadn't been allowed to see before. This was the first convent to accept indigenous women to become nuns in colonial Mexico; it opened its doors in 1724. I had established a relationship with the nuns living in the convent more than fifteen years earlier, and I had visited the convent regularly since then. And yet, during all these years they had only brought me a few files at a time, only of things that had been 
referenced by other scholars, and had never let me take pictures of the documents. That night I sat on the edge of my bed in complete disbelief, feeling a combination of frustration and disappointment. Why, after I had already written a monograph on the convent, and after so many years of visiting it, was I finally allowed to see what was kept in that old, musty, wooden chest? Why didn't they trust me earlier? And what was I supposed to do now? These are complicated questions that made me reflect not only on archives but also on the politics of preservation and accessibility, as well as on the nature of small private archives and dispersed collections housed in larger institutional archives. The history of the Catholic Church in Mexico after independence is turbulent at best, which explains in part the state of the archives related to religious institutions in the country. But there is also the added complication of the fragmented indigenous archive, particularly of the documents that were not produced under the umbrella of the law, and which remain dispersed, and in some instances lost.

The Convent of Corpus Christi's archive represents more than a personal project; that small collection of documents houses the history and the stories of the first indigenous women who were allowed to take the veil in viceregal Mexico. It traces the social networks that were established between different indigenous pueblos and religious communities, and it shows the ways in which indigenous women sought support for their convents from potential benefactors across the Atlantic. Why, then, has this archive remained unknown and inaccessible? What do the state of this archive and that of the lost collections of the indigenous Jesuit colegios and of other schools for indigenous peoples tell us about the writing of history-or the silencing thereof?

Recent scholarship regarding colonial archives has questioned the transparency and objectivity of these repositories, calling attention to the artificial conformation of these spaces; discussions have ranged from reliability of sources to classification issues. These reflections point to an epistemic violence inherent in the praxis of configuring colonial archives, particularly in the cases in which native materials were removed from their local places of knowledge. ${ }^{1}$ The documentation produced and initiated by indigenous peoples related to educational spaces sponsored by the Catholic Church

1. See the discussions on the topic in Kimberly Christen's "Opening Archives" and "Tribal Archives," and in Michelle Caswell. 
during the eighteenth century can be considered an archive that not only contains historical information, but also generates a native epistemology. Yet the cultural materials related to these spaces cannot be located easily in institutional archives, and only partially in small private ones, revealing how certain historiographical narratives have been symbolically annihilated from the official historical record. ${ }^{2}$ As other scholars have done before me, I understand the archive both as a space and as a metaphor for knowledge, power, and memory; ${ }^{3}$ in this way I grant meaning not only to the documents themselves but also to the locations in which they have been kept, and ultimately to the silences and gaps that have been created in the establishment of these archival projects.

The participation of indigenous peoples in the lettered culture of the time provides a window into understanding the role they played in the construction of the kind of national identity that has been propagated since the nineteenth century, which traditionally has been ascribed solely to a generation of educated criollos (people of European ancestry born in the Americas). ${ }^{4}$ Documentation initiated by natives related to ecclesiastical matters, produced in the late colonial period and into the republican period, demonstrates that indigenous peoples maintained a strong ethnic identity and clear awareness of their right to exercise local power.

The religious reforms enacted by the Bourbon rulers in the eighteenth century sought to reduce the power and assets that the Church had amassed in the Americas over the course of two hundred years. Yet Bourbon policies had another purpose: the integration of indigenous peoples through educational reforms, with an emphasis on Spanish-language instruction. Many indigenous communities reinterpreted these initiatives in their favor and used the fissure created between the Crown and the Church to appeal to both authorities for more privileges in religious and educational matters. They advocated for more seminaries and convents exclusively for natives, and ample participation in leadership roles in the parishes of their towns.

Dominant historiographical narratives have hindered the active participation of certain actors in the creation of key discursive practices. In this article,

\footnotetext{
2. Caswell adopted the term symbolic annihilation from feminist media scholars to illustrate what happens when a community is not represented in the archives, or when it is misrepresented (27). 3. Most notably Jacques Derrida and Michel Foucault, but also scholars like Carolyn Steedman, Arlette Farge, and Ann Stoler, to mention just a few.

4. For a lengthier discussion on this topic, see Peter Villella.
} 
I argue that eighteenth-century native elites played a significant role in the larger intellectual scene of colonial Mexico by participating in the same debates as their criollo and European counterparts. I contend that the documentation produced by these native elites related to the indigenous colegios, convents, and seminaries during the eighteenth century provides an important context to understand the ways in which knowledge circulated between natives, criollos, and Europeans. In addition, when this "indigenous archive" is read in tandem with more traditional historiographical native sources, we can better appreciate the indigenous roots of the dominant narrative of Mexican nationalism. In what follows, I discuss the documents that have survived from the Jesuit Colegio de San Gregorio and the Franciscan Convent of Corpus Christi mentioned above in order to reflect on the concept of the archive, and to illustrate the ways in which indigenous knowledge was produced and circulated. I consider the state of these sparse documentary collections by tracing the locations where materials related to these places are housed.

\section{Archives}

Archives continue to be at the center of scholars' concerns, mainly because of their seductive allure. ${ }^{5}$ Jacques Derrida's "Archive Fever" lecture pointed to what some scholars had identified decades before as a consideration worth exploring: the notion of the archive in a kind of Saussurean dichotomy, as both a physical place and a cultural space that give rise to epistemic formations. ${ }^{6}$ In the first few pages of his lecture, Derrida aims at deconstructing the concept of the archive by pinpointing the characteristics that made this place a living space where power, authority, and epistemological considerations were generated. There is no doubt that authority and power contribute to the "feverish desire" of the archive, yet Derrida's characterization and Michel Foucault's earlier theorization of the archive in The Archaeology of Knowledge take us even further. In a familiar poststructural reading, Derrida lingers on the word "archive," analyzing its etymology and granting symbolic

5. For more on the topic, see Farge's The Allure of the Archives, and Zeb Tortorici's "Archival Seduction."

6. His original French title, "Mal d'archive: une impression freudienne," more accurately alludes to the captivating effect of the archive. 
meaning to the word, which in fact ends up complementing and reinforcing what we already knew of the space, which was established by a series of repetitive social practices. Together the arckhe (word) and the arkheion (place) become the origin of all knowledge, and therefore the reason for the uncontrollable desire to possess and to be in the archive (cf. Steedman 6).

Years before Derrida's lecture, Foucault had reflected on the archive, and he had also noted an inherent duality in the concept. On one hand, the archive can be defined by the institution, the documents, and the information contained within it; on the other hand, it focuses on discursive practices and the ways in which these establish a system (128). From that moment on, scholars have aimed at grasping the nature of the archive, describing and defining it. There is no doubt that we have gained immense insight into the configuration of archives thanks to these discussions. However, it is evident that we have not been able to grasp it completely, and we probably never will. In describing the archival space, we endeavor to understand the social practices that gave rise to these places. We see archives, for the most part, as mediating moments between what was done and what can be said about what was done, and between actors and readers of actions. And that is perhaps the main reason why we come back time and again to the archive.

In the last few years, it has been through case studies of particular archives, and on more ethnographic approaches to these spaces, that we have gained the most insight into their formation and purpose. ${ }^{7}$ Ann Stoler explains that the ethnography of the colonial archive "attends to processes of production, relations of power in which archives are created, sequestered, and rearranged" (32); the ethnographic focus ranges from seeing archives as static repositories of material resources to dynamic spaces of epistemological production. These perspectives are not limited by disciplinary boundaries; they reside within the methodological approach we take, and within the kind of reading we carry out: not in the documents housed in the archive, but in the archive as an entity (44).

In his reflections on the archive, Foucault stated that the archive emerges in fragments (130). In an ontological manner, he was alluding to the fact that the archive can only contain moments in one's lifetime, but can never be totalizing. He might have been stating the obvious, but being aware of the

7. Some examples include Caswell's Archiving the Unspeakable, Stoler's Along the Archival Grain, and Kirsten Weld's Paper Cadavers. 
nature of archival spaces may inform the ways in which we approach them. However, archives can also contain a different kind of fragmentation, one inherent to incomplete cases or files. Zeb Tortorici suggests that the seduction of the archives resides precisely in the absences we find in them. As he points out, fragments of cases are more alluring than complete ones (online). We see these fragments housed in archives as windows that allow us to glimpse a moment in time; and the way in which we read a particular instant, the kinds of connections that we are able to draw between that particular moment and the larger composition of the archive, are what grant meaning to an archival fragment, and to the archive as a whole.

While I proposed above that the seductive draw of the archive might reside in the social practices that it encompasses, I nonetheless identify the fragmented nature of the archival space as the feature that allows for these social practices to be deconstructed, analyzed, and understood. The indigenous archive, for instance, emerges in fragments mostly due to the inherent violence of the colonial past and its legacies in the present. Kathryn Burns reflects on indigenous archives, mentioning the books some native groups wrote "without words," which were destroyed almost completely by Europeans. She notes that by the mid-150os the "hybrid notarial culture that native Mexicans were producing" allowed for a fragmented archive mostly written in Spanish and using the language of the law (6). The processes of adaptation, resistance, and change throughout the colonial period were complicated, yet natives found ways to affirm their local power and distinct culture in surprisingly creative ways. By using the same apparatus that had been put in place to dominate them, mainly religious institutions and Spanish law, indigenous peoples actively participated in redefining colonial religious and legal practices.

We have made great strides in our efforts to decolonize knowledge by studying sources produced by natives and reading them alongside official European documents; however, Mexican historiography has, for the most part, privileged certain sources and left others in the margins. The difficulty of locating documentation produced or initiated by natives in institutional archives, and in the public domain, has brought to our attention the need to rearticulate the ways in which we have understood what constitutes knowledge. I would claim that the absence of indigenous materials in archives and the systematic removal of native cultural materials from local knowledge systems is closely linked to the colonial and neocolonial legacies inherited from the European Renaissance and the Enlightenment, which have 
informed the ways in which we have forgotten or ignored native epistemologies (Mignolo 25).

Archives can then be defined in different ways, and perceived according to their fragmented nature. Antoinette Burton describes archives as "traces of the past collected either intentionally or haphazardly as evidence, and which are by no means limited to official spaces or state repositories" (3). The indigenous archive that I am dealing with fits these characteristics, given that the paper trail that I have been tracing is not limited to the official spaces of institutional archives, and many of the documents were kept arbitrarily. By putting together these apparently unrelated and inconsequential documents and reading them as part of a larger project, we can transform seeming fragments into a coherent history that builds on the narrative of a glorious indigenous past that informs Mexican nationalism.

\section{Indigenous Peoples and the Church}

The mendicant orders arrived in Mexico soon after Cortés and his allies took control of Tenochtitlan. The Franciscans were the first religious order to begin evangelizing the indigenous population, focusing on their education as well. Franciscans founded the Colegio de Santa Cruz de Tlatelolco in 1536 for the native nobility, with the support of the Crown. The school was known for producing a generation of Nahua intellectuals who transcribed in alphabetic writing and translated into Spanish pre-Hispanic painted documents, and collaborated with Spanish friars in the evangelization of the rest of the indigenous community. ${ }^{8}$ By the end of the sixteenth century, royal funds for the maintenance of the school decreased, until they eventually ceased altogether, limiting the purpose of the school to the teaching of Christian doctrine and Spanish.

The Jesuits also opened a school for the indigenous nobility in 1586 near the city's center, the Colegio de San Gregorio. ${ }^{9}$ The school relied on private funds for its maintenance, and profited from the properties the school owned, particularly the hacienda de Acolman. The Jesuits taught natives European rhetoric, music, Latin, and other subjects. For various reasons,

\footnotetext{
8. For a lengthy discussion of the Colegio de Tlatelolco, see Rocío Cortés.

9. The Jesuits first opened a school in Tepotzotlán in 1580 for the children of the nobility, but it later became a seminary, and not exclusively a colegio for natives.
} 
the school seems to have simplified the curriculum dedicated to indigenous education during the seventeenth century, but saw a revival in its educational mission by the eighteenth century. The lack of archival documentation from the Colegio de San Gregorio and other educational and religious spaces for natives has fostered a historiographical narrative that stresses the decline of these spaces by the seventeenth century and their later disappearance. ${ }^{10}$

The education of indigenous women in Mexico during the colonial period developed more slowly. Initially, religious orders had an interest in instructing indigenous girls in the faith so they could become nuns; however, colonial officials rejected this idea because they believed that indigenous women lacked the abilities required for life in the convent (Muriel 26). The first convents founded in New Spain were devoted to Spaniards and criollas, and during the first two hundred years of colonial life, indigenous women could enter convents only as servants. There were, however, some schools that opened with the purpose of teaching indigenous girls Spanish and to pray. The first convent exclusively for indigenous noblewomen, the Convent of Corpus Christi, opened its doors in 1724. The second convent was founded in present-day Morelia thirteen years later, and the third one in 1782 in the city of Antequera (present-day Oaxaca); all three were exclusively for indigenous noblewomen.

A shift in cultural politics took place during the eighteenth century that affected the development of the schools and the foundation of convents and seminaries for indigenous peoples. Some of the reforms introduced by the Bourbon monarchy regarding educational campaigns in indigenous communities were interpreted by natives as opportunities to restore already existing spaces for education and to open additional ones. While the Franciscan Colegio de Tlatelolco and the Jesuit school for natives experienced a golden age in the sixteenth century that did not continue throughout the rest of the colonial period, their legacy endured for years and persisted in clear ways. Franciscans and Jesuits fostered the creation of a generation of educated natives who became intermediaries, historians, officers in local government, grammarians, translators, and keepers of pre-Hispanic documents and

10. Important work that has recovered some of the history of San Gregorio has been done by Ileana Schmidt Díaz de León, and in general about indigenous education in colonial Mexico by Dorothy Tanck de Estrada. 
historical memory. Moreover, they encouraged native education, promoted the preservation of indigenous archives, and fostered social networks that contributed to the advancement of a select portion of the indigenous population.

Education gave indigenous peoples opportunities to improve their social position, and in many instances to claim ancestral rights. Throughout the years of Spanish colonial rule, indigenous peoples collaborated with Spaniards and criollos, intermarried, and became mestizos or castizos, yet many continued identifying with the native population. By the eighteenth century the social and political structure that would produce the petitions for additional spaces for education or for the restoration of old ones had already been laid out, both in terms of collaborative networks across ethnic and religious groups and the number of educated natives in positions of power who belonged to generations of intellectuals. Perhaps because educational efforts dedicated to indigenous peoples were closely related to the Church from the beginning of colonization, or because the Church opened opportunities that allowed them to maintain a cohesive identity through religious practices and spiritual resources (O'Hara 58), when caciques sought more opportunities for the education of both men and women, they petitioned for spaces related to the Church.

Caciques articulated their needs for education in accordance with enlightened paradigms. Traditionally, the Enlightenment has been considered a mostly antireligious phenomenon born in Europe. However, recent scholarship has proposed a more nuanced understanding of this phenomenon. ${ }^{11}$ Charles R. Kesler suggests that there were many different enlightenments that flourished in different parts of the world at various times and with distinct characteristics (102). This contradicts the established notion of a monolithic Enlightenment and acknowledges it as a global phenomenon with different expressions and possibilities. One of these expressions is the Catholic or moderate enlightenment, mostly experienced in southern Europe and in the Americas. ${ }^{12}$ Enlightened ideas circulated through cultural, intellectual, and social exchanges in a globalized manner during the eighteenth century. The

\footnotetext{
11. See the special issue of Colonial Latin American Review dedicated to the Latin American enlightenments edited by Mariselle Melendez and Karen Stolley.

12. See, for example, Gabriel Paquette's Enlightenment, Governance, and Reform in Spain and Its Empire.
} 
circulation of ideas through the publication of newspapers such as the Mercurio Peruano in Lima, and the Gazeta de Literatura de México, and the founding of academic societies and scientific academies attest to the enlightened character of these cities (Meléndez and Stolley 1-2). But the Catholic enlightenment also involved new circumstances in which knowledge was produced, as in the case of Mexico and the educational context which had historically been in the hands of the Church. ${ }^{13}$ Indigenous peoples appealed to both ecclesiastical and secular authorities for the opening of convents and schools, but ultimately sought to achieve their goals by aligning their petitions with the rhetoric of the laws that had granted them privileges as nobles and as vassals of the Crown who accepted Christianity and aided in the religious conversion of their pueblos.

I see the indigenous archives that I am working with not as defined locations, but rather as the paper trail that contains the knowledge and historical memory of a group of indigenous peoples, more specifically of those who participated in some of the educational institutions sponsored by the Catholic Church. This paper trail is scattered in different places, and when brought together and read as one cultural project, it sheds light on an important part of the history of natives in Mexico. The fact that these documents are dispersed in many different locations also speaks to the systematic removal of indigenous cultural materials from local knowledge systems and from the communities to which they belonged (Christen, "Tribal Archives" 2).

It is important to clarify that I am labeling this particular paper trail an "indigenous archive," yet I don't mean to imply that this is the only indigenous archive. In fact, what I am tracing is similar in many ways to the "native archive" studied by Amber Brian in her book Alva Ixtlilxochitl's Native Archive in that it contains native knowledge; she defines it as "the knowledge native communities collected in an effort to preserve their connection to the pre-Hispanic past in the context of European domination" (14). However, the fragmented indigenous archive that I am interested in differs from Brian's mostly in the purpose and nature of the documents that are contained in it. Yet at the same time, it builds on it, expands it, and contributes to the efforts to trace a historical memory of indigenous epistemologies.

13. I have explored this in more detail in "The Education of Natives." 


\section{Corpus Christi and San Gregorio}

As mentioned above, I am only focusing this reflection on two spaces that illustrate the point about the fragmented indigenous archive, yet these are not the only spaces that could be mentioned. Although dissimilar in many ways-one was founded in the sixteenth and the other one in the eighteenth century; one was devoted to women, and the other to men-the Convent of Corpus Christi and the Colegio de San Gregorio were equally important for the native community of central Mexico. The convent represented the first and only cloister that admitted indigenous women as nuns in Mexico City until the early nineteenth century, and the Jesuit colegio was the oldest school still in operation where indigenous men could acquire an education that went beyond the basic knowledge of Spanish and Christian doctrine. Moreover, San Gregorio was not limited to the education of noblemen: it included a public school for the commoners, or macehuales; it was a hub for missionary work in different pueblos; and later in the eighteenth century it also housed two indigenous congregations and a school for indigenous girls (Schroeder 52).

Through archival research, I was also able to identify a still more direct connection between the eighteenth-century Franciscan Convent of Corpus Christi and the Jesuit colegio: San Gregorio kept a fund intended to support the entrance of orphan girls into the Convent of Corpus Christi (BMNAHCSG, vol. 127, ff. 148r-149v; vol. 133, ff. 159r-16ov). Widowed mothers would request support for their daughters from those in charge of this San Gregorio fund. While the convent did not require a dowry for entrance, it did expect the novice to possess certain funds to pay for the ceremony of profession, among other miscellaneous expenses. Through the economic resources that the Jesuit colegio had amassed in its two centuries of life, social networks were established between the natives of the colegio, the creole priests, and other indigenous corporations, creating an important web of support and cultural presence in colonial society.

Most of the archival documentation from San Gregorio that has been located and studied has to do with its finances, especially during certain key moments of its life: its foundation, the donation of the hacienda de Alcoman at the end of the seventeenth century, the expulsion of the Jesuits in 1767 , and Mexican independence in 1821. Little is still known about the intellectual life of the colegio and the curriculum that was used, and most of the historiographical narrative that exists about it has to do with the way in which archival silences and fragments have been read and interpreted. I argue, for 
example, that the knowledge that certain eighteenth-century Jesuits acquired of ancient Mexico and of indigenous languages did not depend only on bibliographical and documentary research but on their daily interactions with educated natives who lived in San Gregorio. Such was the case of wellknown Jesuit Francisco Javier Clavijero, author of Historia antigua de México.

Clavijero was sent in 1758 from Tepotzotlán to San Gregorio, where he continued studying Nahuatl, and he soon became one of the confessors at San Gregorio (Ronan 14). It is said that he would visit the library at the Colegio de San Pedro y San Pablo, adjacent to San Gregorio, to study the Mexican codices that were kept there. In his Historia, in which he passionately defends Mexico, its culture, and its peoples in response to some of the criticisms of enlightened Europeans, Clavijero explicitly states having dealt closely with indigenous students and priests (224). We lack documentation that specifies the names of these natives, and Clavijero doesn't mention them by name either; however, this mention is key to exploring the possible intellectual collaborations that existed between educated natives and creole priests, as well as the kind of education that natives received over the years of the school's life. These concerns have led to my interest in piecing together the Colegio de San Gregorio's archive, and are intended to provide a contrasting narrative to the one we know about indigenous education in Mexico.

What has remained from the Jesuit colegio is housed mainly in the Archivo General de la Nación (AGN) and in the Biblioteca del Museo Nacional de Antropología e Historia (BMNAH) in Mexico City. Peripheral references and minor correspondence can also be located in the Jesuit Biblioteca Eusebio Francisco Kino in Coyoacán. It is possible that additional documentation may be located in other Jesuit archives in Chile, Rome, or Spain, but to date nothing substantial has been found. Yet even when we know that documentation about the colegio exists in these archives, there is no straightforward, transparent way to access it. As Stoler aptly states, there is an inherent lack of transparency in the way colonial archival collections are organized. That lack of transparency does not necessarily refer to accessibility. Rather, it has to do with how colonial sense and reason conjoined social kinds with the order of things (9). The place that natives occupied in colonial society, and the notions related to them, are reflected in the ways their lives were documented and preserved in institutional archives. Moreover, the expulsion of 
the Jesuits from Spain and its colonies added another element of marginalization to the documentation produced in and around the colegios for indigenous peoples sponsored by the Jesuits. Much of the documentation was destroyed after the expulsion, and in some instances simply removed from the place where it was produced. The scant references found are fragments, incomplete pieces of a larger cultural picture.

Although different from San Gregorio, Corpus Christi also suffered a similar fate in terms of its documentation. It is common knowledge among the nuns of the present-day convent that some of their most valuable documents and other religious artifacts were taken from the cloister without their consent by one of their benefactors in the early twentieth century. The bestknown manuscript produced in the eighteenth century about the convent was published in 1963 by Josefina Muriel with the title Las indias caciques de Corpus Christi, and it is now housed in the Biblioteca Nacional at UNAM. The Franciscan nuns are not certain when the manuscript left the convent but it never returned to the cloister, where they claim it belongs. Perhaps because of this history of dispossession and the perceived persecution that the Catholic Church suffered under the Reform Laws in the nineteenth century, the nuns are wary of any historian who shows up at the convent's door asking to see its archive. In addition to what is housed in the convent, there are some documents in the AGN, in the BMNAH, and in the National Library at UNAM.

Piecing together a history of indigenous knowledge in the eighteenth century requires persistence and creativity. Part of the problem is historiographical: the incursion of indigenous peoples into what is perceived as a European institution, such as the Catholic Church, has been pushed to the margins of the more dominant version of history. Yet a larger challenge is the fragmented state of the eighteenth-century indigenous archive due to the "common sense" (or lack thereof) of colonial organization and preservation of native epistemologies, particularly those related to education and religion. One of the cases that I have started to put together through archival research is the petition initiated by the nuns of Corpus Christi to open a convent in the city of Puebla in 1779. Some of the documentation related to this petition seems to have been recently catalogued at the AGN. A search in the archive's catalogue using the same search terms in the 1990s and in the early 2000 did not show any results for the Puebla petition, yet a decade later, it appeared with other documents related to indigenous convents. Moreover, some 
important additional documentation can be found in the convent's archive. The dispersed materials related to this petition is a case in point of how colonial organization of documentation, and present-day politics of historical preservation, can jeopardize the integrity of indigenous archives.

Given the recent expulsion of the Jesuits from Mexico, the nuns of Corpus Christi petitioned to use the building of the former Jesuit Colegio de San Francisco Xavier (built for natives) for their new convent. That same year, a royal decree was issued to begin an investigation with the bishop and other religious authorities in the city of Puebla regarding the need for the cloister. The documentation available offers two slightly different versions of what happened. One version, most of which is located in the AGN, reveals the negative response of Puebla's bishop, Victoriano López, who argued that there were too many cloisters already in the city and therefore no need for any more. This version coincides with the subsequent issuance of another royal decree from 1785 denying support for the convent's foundation.

The second version, presented by the indigenous nuns and now housed in the convent, states that the report on the need for its foundation never reached the King. Certain religious authorities, such as the cabildo of the cathedral in Mexico City, supported this version, and this support encouraged sor María Dominga de Santa Coleta, and later sor María Manuela del Corazón de Jesús, two of the nuns at Corpus Christi, to continue petitioning for the cloister. Once Bishop López left his post, the nuns of Corpus Christi saw another opportunity to renew their plea. Their efforts to obtain the necessary support for their proposed convent are remarkable. They asked indigenous leaders from various communities who could potentially benefit from the new cloister to write letters in support of its foundation. There is a letter of support written by the governor of Tehuacán de las Granadas addressed to the new bishop, Salvador de Bienpica y Sotomayor; another one composed by the governor of Tepeaca; one from the governor of Huexotzinco; and another from the governor of Tlaxcala. The nuns also secured the support of the new bishop in the city of Puebla, who found a space for the cloister by the Chapel of Our Lady of Dolores. As late as 1790, the nuns of Corpus Christi addressed a petition directly to the Queen of Spain, and by 1802, the foundation had received support from the viceroy. Despite all of this activity, the cloister never materialized.

As in the case of San Gregorio, with the petition for the convent in Puebla, it is possible to glimpse the social networks that were established and that went beyond ethnicity, religious orders, and geographical areas. The nuns 
received considerable support from the political leaders of several indigenous pueblos, as well as from representatives of the Church who viewed the idea of the convent as a positive one for the natives of Puebla and Mexico City. These networks promoted education and, in general, opportunities for both men and women to improve their lives and their place in society. In addition, they provided a support system that ranged from financial resources to a sense of community without ethnic or regional divides.

In conclusion, the close contact with religious institutions and experience with Spanish literacy that indigenous peoples had developed early in the colonial period allowed them to become familiar with an intellectual tradition and with the bureaucracy and rhetoric of the ecclesiastical courts. This knowledge became the basis for demanding additional spaces like convents and seminaries exclusively for their communities. Although the convents and seminaries that they sought were aligned with, and supported, the dominant colonial culture, these institutions brought honor to their pueblos, and provided spaces where groups of ethnically heterogeneous indigenous people could maintain a certain level of local power and solidarity. In these spaces that the Church conferred on them, indigenous people were able to maintain a cohesive identity as indios and achieve a certain power in colonial society.

By the twentieth century however, the religious apparatus that had allowed for those opportunities no longer existed, at least not as it did during the colonial period. The difficult financial situation of many religious communities in present-day Mexico, and their shrinking numbers, speaks loudly to the effects of the Reform laws of the nineteenth century and their legacies into the twentieth and twenty-first centuries. In many cases, little is left of the grandiose religious culture that these spaces experienced, and even less is left of the paper trail that tells the history of their inhabitants. The nuns of the Convent of Corpus Christi had ample reason to be suspicious of anyone asking to see the materials they had kept in their convent, especially after having experienced a history of dispossession and, to a certain extent, persecution. Once I established a relationship of trust with them, they allowed me to see the documents they had been able to keep dating back to the eighteenth century, yet they feared that if I publicized the existence of the archive, they would be a target for an institutional archive to remove their most precious materials from the convent. The fragility of the paper trail of indigenous knowledge that is located in this convent's archive represents only one of many similar cases that exist in Mexico today.

The state of fragmentation of indigenous archives invites us to develop an 
awareness of the ways in which biases exist in our understanding of a national patrimony in Mexico today. In order to continue decolonizing native epistemologies, we need to rethink the ways in which colonial archives have been traditionally constituted and question what has traditionally comprised native knowledge. Shouldn't all the reflection and discussion about archives that has taken place in the last twenty years or so lead us to address historical injustices and make archives places of reconciliation for the communities who own them? Shouldn't we create protocols for indigenous peoples to access these archives and incorporate them as part of their history? These are also complicated questions that resist easy answers. My interest has been in making these documents speak and tell us a story that we did not know until now. But we also need to address institutional and governmental policies that make decisions about what constitutes national patrimony. I trust that academics can make a difference in addressing these issues in the near future.

\section{Works Cited}

AGN (Archivo General de la Nación). Mexico City.

BMNAH-CSG (Biblioteca del Museo Nacional de Antropología e Historia-Colegio de San Gregorio). Mexico City.

Brian, Amber. Alva Ixtlilxochitl's Native Archive and the Circulation of Knowledge in Colonial Mexico. Vanderbilt UP, 2016.

Burns, Kathryn. Into the Archive: Writing and Power in Colonial Peru. Duke UP, 2010.

Burton, Antoinette. "Introduction: Archive Fever, Archive Stories." Archive Stories: Facts,

Fictions, and the Writing of History, edited by Antoinette Burton, Duke UP, 2005, pp. 1-24.

Caswell, Michelle. "Seeing Yourself in History: Community Archives in the Fight Against Symbolic Annihilation.” The Public Historian, vol. 36, no. 4, 2014, pp. 26-37.

Christen, Kimberly. “Opening Archives: Respectful Repatriation.” The American Archivist, no. 74, 2011, pp. 185-210.

—. "Tribal Archives, Traditional Knowledge, and Local Contexts: Why the ' $\mathrm{s}$ ' Matters." Journal of Western Archives, vol. 6, no. 1, 2015, pp. 1-21. http://digitalcom mons.usu.edu/cgi/viewcontent.cgi?article $=1046 \&$ context $=$ westernarchives.

Clavijero, Francisco Javier. Historia antigua de México. Vol. 4, edited by Mariano Cuevas, Porrúa, 1959.

Cortés, Rocío. “The Colegio Imperial de Santa Cruz de Tlatelolco and Its Aftermath: Nahua Intellectuals and the Spiritual Conquest of Mexico." A Companion to Latin American Literature and Culture, edited by Sara Castro-Klarén, Blackwell, 2008. 
Díaz: the indigenous archive 183

Derrida, Jacques. “Archive Fever: A Freudian Impression.” Diacritics, vol. 25, no. 2, 1995, pp. 9-63.

Díaz, Mónica. "The Education of Natives, Creole Clerics, and the Mexican Enlightenment." Colonial Latin American Review, vol. 24, no. 1, 2015, pp. 60-83.

Farge, Arlette. The Allure of the Archives. Yale UP, 2013.

Foucault, Michel. The Archeology of Knowledge, and the Discourse on Language. Vintage Books, 1976.

Kesler, Charles. "The Different Enlightenments: Theory and Practice in the Enlightenment." The Ambiguous Legacy of the Enlightenment, edited by William A. Rusher, UP of America, 1995, pp. 102-19.

Meléndez, Mariselle, and Karen Stolley. "Introduction: Enlightenments in IberoAmerica." Colonial Latin American Review, vol. 24, no. 1, 2015, pp. 1-16.

Mignolo, Walter. The Darker Side of the Renaissance: Literacy, Territoriality, and Colonization. U of Michigan P, 1995.

Muriel, Josefina. Conventos de monjas en la Nueva España. Jus, 1995. Originally published by Editorial Santiago, 1946.

O'Hara, Mathew. A Flock Divided: Race, Religion, and Politics in Mexico. Duke UP, 2010.

Paquette, Gabriel. Enlightenment, Governance, and Reform in Spain and Its Empire, 17591808. Palgrave Macmillan, 2008.

Ronan, Charles. Francisco Javier Clavijero, S. J. (1731-1787), Figure of the Mexican Enlightenment: His Life and His Works. Loyola UP, 1977.

Schmidt Díaz de León, Ileana. El colegio seminario de indios de San Gregorio y el desarrollo de la indianidad en el centro de México, 1586-1856. Plaza y Valdés, 2012.

Schroeder, Susan. "Jesuits, Nahuas, and the Good Death Society in Mexico City, 17101767." Hispanic American Historical Review, vol. 80, no. 1, 2000, pp. 43-76.

Steedman, Carolyn. Dust: The Archive and Cultural History. Rutgers UP, 2002.

Stoler, Ann Laura. Along the Archival Grain: Epistemic Anxieties and Colonial Common Sense. Princeton UP, 2009.

Tanck de Estrada, Dorothy. Pueblos de indios y educación en el México colonial, 1750-1821. El Colegio de México, 1999.

Tortorici, Zeb. "Archival Seduction: Indexical Absences and Historiographical Ghosts." Archive Journal, 2015, http://www.archivejournal.net/essays/archival-seduction/.

Villella, Peter. Indigenous Elites and Creole Identity in Colonial Mexico, 1500-180o. Cambridge UP, 2016.

Weld, Kirsten. Paper Cadavers: The Archives of Dictatorship in Guatemala. Duke UP, 2014. 